\title{
OCCURRENCE OF LEOPARD SEALS IN NORTHERN ARGENTINA
}

\author{
Diego Rodríguez ${ }^{1,2,}$, Ricardo Bastida ${ }^{1,2}$, Sergio Morón ${ }^{3}$, Sergio Rodríguez Heredia ${ }^{3}$, and Julio Loureiro ${ }^{3}$
}

The leopard seal (Hydrurga leptonyx de Blainville 1820) is widely distributed on the Antarctic pack ice and south to the edge of the continent, with seasonal northward movements related with ice conditions (Erickson et al., 1971; Kooyman, 1981; King, 1983). The distribution also includes small permanent concentrations in Antarctic and Subantarctic islands as Heard (Gwyn, 1953; Brown, 1957), Auckland, Campbell (King, 1983; Reeves et al., 1992) and Kerguelen (Bester, 1981; Bester and Roux, 1986; Borsa, 1990). Small seasonal groups are also recorded in MalvinasFalkland (Hamilton, 1939; Laws, 1953), South Georgia (Hamilton, 1939; Walker et al., 1998) and Macquarie (Rounsevell and Eberhard, 1980) Islands.

In the western South Atlantic a limited number of solitary leopard seals were found in Brazil (Widholzer, 1982; Ximenez et al., 1987; Pinedo; 1990; Rosas et al., 1992; Ferreira et al., 1995), Uruguay (Vaz Ferreira, 1984; Naya and Achaval, Ms.), Tierra del Fuego (Goodall and Schiavini, 1987) and Patagonia (Crespo et al., 1992). In northern Argentina the only record of a leopard seal was a male killed in Puerto Quequén in the forties (Castello and Rumboll, 1978). Beach surveys in northern Buenos Aires Province $\left(36^{\circ} 20^{\prime}-38^{\circ} 35^{\prime} \mathrm{S}\right)$ since 1987 resulted in four new records (Table 1 ).

The seals presented a poor physical condition and died a few hours later (records 8 and 9) or only the carcass was found (record 11); no food traces were found in the digestive tracts. The fourth animal (record 10) was alive but deeply wounded and unable to move. It could not be recovered for rehabilitation on this day and on the subsequent day we were unable to find it. It presumably died and the body lost during high tide. In the marine mammal collections of Buenos Aires and La Plata Museums in Argentina no additional leopard seal material from northern Argentina is deposited.

Leopard seals in northern Argentina were found between June and December, in agreement with the record of vagrants in Patagonia, Uruguay and Brazil. Ninety percent of the leopard seal vagrants are recorded from June to September (Figure 1). Similar seasonal patterns are recorded in South Georgia (April-November; Walker et al., 1998), Macquarie (July-November; Gwyn, 1953), MalvinasFalklands (spring and early summer; Hamilton, 1939) and Kerguelen (May-November; Bester, 1981; Kooyman, 1981; Bester and Roux, 1986; Borsa, 1990). A 3-5 yr. periodic peak of record of solitary seals has been suggested for Macquarie (Rounsevell, 1988; Testa et al., 1991) and South Georgia Islands (Walker et al., 1998).

Although not all measured, most of the animals were juveniles ranging from $200-250 \mathrm{~cm}$, corresponding to animals less than 3 years old (Hamilton, 1939; Brown, 1957). The presence of immature seals was also noted in Macquarie (Rounsevell 1988), Kerguelen (Borsa, 1990) and South Georgia (Walker et al., 1998) Islands, but contrasts with the situation in Tierra del Fuego, where leopard seal vagrants are predominantly adults (4-25 years; Goodall and Schiavini, 1987). Laws (1957) and Hofman et al. (1977) suggested regional segregation by age, whereas the predominant presence of males in the western South Atlantic suggests a possible segregation or different dispersal capabilities by sex.

The pattern of occurrence of leopard seals in northern Argentina seems to be related both to feeding strategies and to the annual cycle of the species. Leopard seals are characterised as the most catholic of the seals, including penguin, seals, squid, crustaceans and fish in their diet (Hamilton, 1939; Gwyn, 1953; Brown, 1957; Hoffman et al., 1977; Kooyman, 1981; Siniff and Stone, 1985). Changes in prey occurrence were reported along the years, with seals and penguins being important during pupping and fledging periods in summer. Siniff and Stone (1985) recorded an increase in krill occurrence during winter and suggested a potential winter competition with krill eaters (crabeater seals and Adelie penguins). Young leopards may have not the ability to exploit large prey like seals and penguins (Siniff and Bengstone, 1977; Walker et al., 1998) and may be excluded by competition with the consequent influence in the dispersion of younger seals to northern areas. It was also suggested that older leopard seals might compete for accessing to areas of high resource concentration as seal and penguin colonies, excluding younger individuals (Bester and Roux, 1986; Borsa, 1990). The impoverished health condition found in animals from northern Argentina maybe an indicator of such dietary stress and was also recorded for young leopard seals in Kerguelen (Borsa, 1990). In areas of high concentration of potential prey as South Georgia, the animals are found in very good physical conditions (Walker et al., 1998).

The sharp increase of the number of crabeater seal pups available as prey in November (Siniff et al., 1979) and the pack-ice recession, corresponds with the declining record of Hydrurga vagrants in Subantarctic areas. The leopard seal breeding season also begins approximately in November when most of the births occur (Hamilton, 1939; Brown, 1957; DeMaster et al. 1979; Laws, 1984; Siniff and Stone, 1985), with mating apparently concentrated shortly after weaning in January-March

\footnotetext{
'Departamento de Ciencias Marinas, Facultad de Ciencias Exactas y Naturales, Universidad Nacional de Mar del Plata. Casilla de Correos 43, Mar del Plata, 7600, Argentina.

${ }^{2}$ Consejo Nacional de Investigaciones Científicas y Técnicas, Argentina.

${ }^{3}$ Fundación Mundo Marino, Avenida Décima s/n, San Clemente del Tuyú, 7105, Argentina.

• Corresponding author. E-mail: dhrodri@mdp.edu.ar, FAX +54 223 475-3150.
} 
Table 1. Records of Hydrurga leptonyx in the western South Atlantic.

\begin{tabular}{|c|c|c|c|c|c|c|c|}
\hline RECORD & DATE & SEX & $\begin{array}{c}\text { LENGTH } \\
(\mathrm{cm})\end{array}$ & LOCALITY & COUNTRY & LATITUDE & REFERENCE \\
\hline 1 & 5 Aug., 1989 & - & $210\left(^{*}\right)$ & Rio de Janeiro & Brazil & $21^{\circ} 40^{\prime} \mathrm{S}$ & Rosas et al., 1992 \\
\hline 2 & ?, 1964 & $0^{\prime}$ & $-\left({ }^{*}\right)$ & Florianópolis & Brazil & $27^{\circ} 40^{\prime} \mathrm{S}$ & Ximenez et al., 1987 \\
\hline 3 & ? June, 1981 & $\sigma^{\prime}$ & - & Praia de Cidreira & Brazil & $30^{\circ} 00^{\prime} \mathrm{S}$ & Widholzer, 1982 \\
\hline 4 & 16 Sept., 1986 & $0^{\prime}$ & ? 200 & Praia do Cassino & Brazil & $32^{\circ} 07^{\prime} \mathrm{S}$ & Pinedo, 1990 \\
\hline 5 & 27 Aug., 1994 & - & 200 & Albardão & Brazil & $33^{\circ} 15^{\prime} \mathrm{S}$ & Ferreira et al., 1995 \\
\hline 6 & ? Aug., 1981 & - & $? 243\left(^{*}\right)$ & Punta Palmar & Uruguay & $34^{\circ} 03^{\prime} \mathrm{S}$ & Vaz Ferreira, 1984 \\
\hline 7 & 18 Sept., 2000 & q & 225 & Playa Piriápolis & Uruguay & $34^{\circ} 25^{\prime} \mathrm{S}$ & Naya and Achaval, Ms. \\
\hline 8 & 21 Dec., 1987 & $\sigma$ & - & San Clemente del Tuyú & Argentina & $36^{\circ} 21^{\prime} \mathrm{S}$ & Present Paper \\
\hline 9 & 1 June,1989 & - & - & San Clemente del Tuyú & Argentina & $36^{\circ} 21^{\prime} \mathrm{S}$ & Present Paper \\
\hline 10 & 15 Aug.,2002 & ㅇ & $? 300$ & San Clemente del Tuyú & Argentina & $36^{\circ} 21^{\prime} \mathrm{S}$ & Present Paper \\
\hline 11 & 3 Sept., 1995 & - & $-\left(\psi^{*}\right)$ & Mar de las Pampas & Argentina & $38^{\circ} 05^{\prime} \mathrm{S}$ & Present Paper \\
\hline 12 & $?, 1944$ & $\sigma$ & 266 & Puerto Quequén & Argentina & $38^{\circ} 35^{\prime} \mathrm{S}$ & Castello and Rumboll, 1978 \\
\hline 13 & 1 Aug., 1994 & - & - & Balneario El Cóndor & Argentina & $41^{\circ} 05^{\prime} \mathrm{S}$ & Crespo et al., 1992 \\
\hline
\end{tabular}

Obs.: $(\psi)$ incomplete skeleton recovered and deposited in the Marine Mammal Research Group Collection of Universidad Nacional de Mar del Plata, with serial number GMM-HL-001; (*) cranial measurements included in Table 2.

\section{Occurrence of leopard seals in the western South Atlantic}

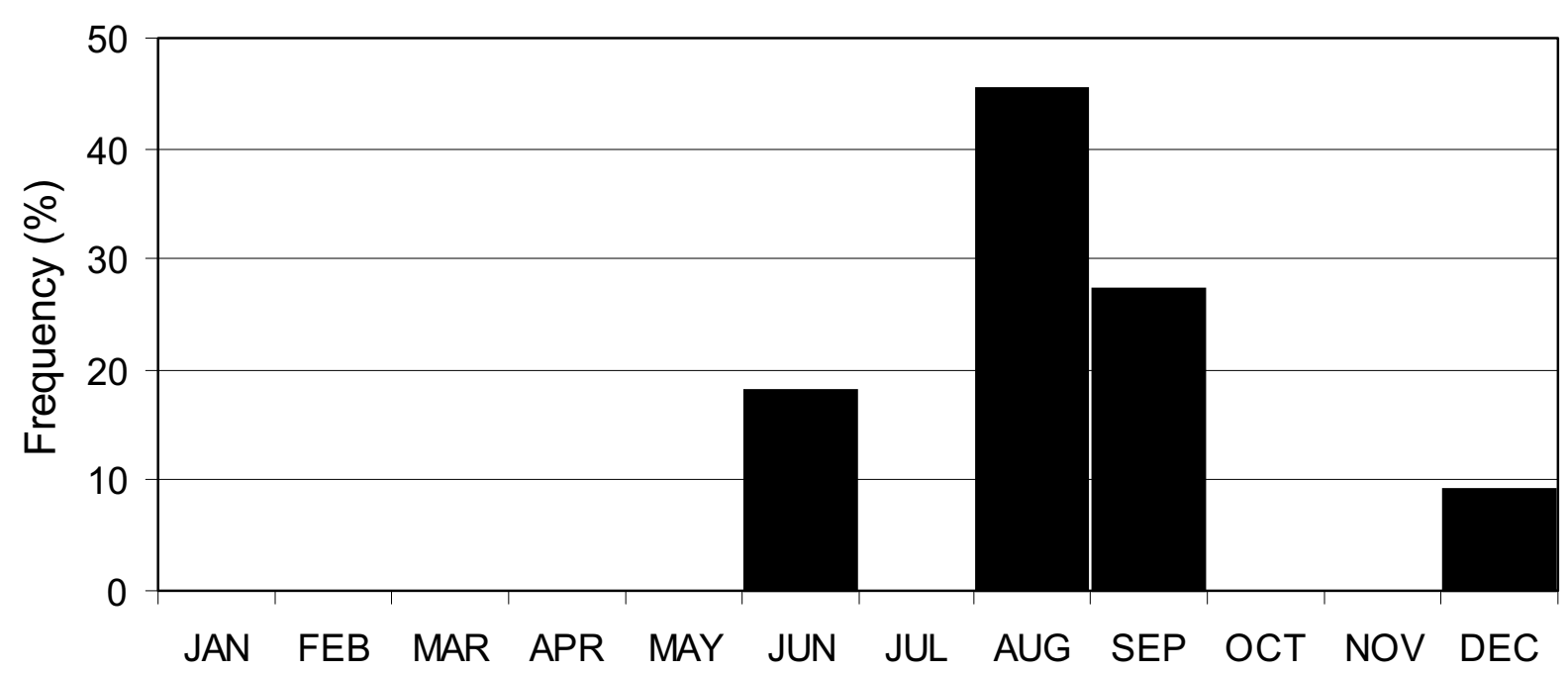

Figure 1. Monthly occurrence of leopard seals in the western South Atlantic, from a total of eleven records of Brazil (Widholzer, 1982; Pinedo; 1990; Rosas et al., 1992; Ferreira et al., 1995), Uruguay (Vaz Ferreira, 1984; Naya and Achaval, Ms.) and Argentina (Crespo et al., 1992; present paper).

(Hamilton, 1939; Harrison, 1969; Sinha and Erickson, 1974). Sightings of leopard seals sharply decrease in the pack ice by mid-November to late December, coinciding with the mating period (Hofman et al., 1977; Siniff and Stone, 1985).

The occurrence of leopard seals in temperate areas of the western South Atlantic from early winter to late spring is directly related with the northward dispersal of immatures from the Antarctic pack ice. Food competition during winter may force such animals to forage in Subantarctic areas close to South America and transported by the Malvinas-Falkland current to coastal areas. The onset of the breeding season and the increase of potential prey available around Antarctica may influence the sharp decline of the records at the beginning of the summer. 
Table 2. Cranial measurements of Leopard seals found in the western South Atlantic.

\begin{tabular}{|c|c|c|c|c|c|c|c|c|}
\hline \multirow{2}{*}{ Measurement (mm) } & \multicolumn{2}{|c|}{ Present Paper } & \multicolumn{2}{|c|}{ Rosas et al., 1992} & \multicolumn{2}{|c|}{ Ximenez et al., 1987} & \multicolumn{2}{|c|}{ Vaz Ferreira, 1984} \\
\hline & Absolute & $\%$ & Absolute & $\%$ & Absolute & $\%$ & Absolute & $\%$ \\
\hline Condylobasal Length & 326.0 & 100.0 & 314.0 & 100.0 & 389.0 & 100.0 & 330.0 & 100.0 \\
\hline Basilar Length of Hensel & 285.0 & 87.4 & 284.0 & 90.4 & 369.0 & 94.9 & - & - \\
\hline Greatest Length of Nasals & 81.9 & 25.1 & 101.0 & 32.2 & - & - & - & - \\
\hline Width of Nasals & 24.9 & 7.6 & - & - & - & - & - & - \\
\hline Greatest Width of Nasal Aperture & 39.4 & 12.1 & - & - & - & - & - & - \\
\hline Width at Preorbital Processes & 99.6 & 30.6 & 87.0 & 27.7 & - & - & - & - \\
\hline Palatal Notch-Incissors & 116.0 & 35.6 & 120.0 & 38.2 & - & - & - & - \\
\hline Hamulo-premaxilar Length & - & - & 196.0 & 62.4 & - & - & 190.0 & 57.6 \\
\hline Width of Skull at Canines & 60.8 & 18.7 & 61.0 & 19.4 & - & - & - & - \\
\hline Length of Snout & 61.9 & 19.0 & - & - & - & - & - & - \\
\hline Width of Zygomatic Root of Maxilla & - & - & 34.0 & 10.8 & - & - & - & - \\
\hline Width of Palate at 5th Postcanine & 66.0 & 20.2 & 65.0 & 20.7 & - & - & - & - \\
\hline Width at Pterygoid Hamuli & 52.0 & 16.0 & - & - & - & - & - & - \\
\hline Palatal Margin to Pterygoid Suture & 37.8 & 11.6 & - & - & - & - & - & - \\
\hline Interorbital Width & 39.6 & 12.1 & 40.0 & 12.7 & - & - & 39.0 & 11.8 \\
\hline Zygomatic Width & 167.0 & 51.2 & 157.0 & 50.0 & 225.0 & 57.8 & 185.0 & 56.1 \\
\hline Mastoid Width & 171.0 & 52.5 & 159.0 & 50.6 & - & - & - & - \\
\hline Auditory Width & 149.3 & 45.8 & 146.0 & 46.5 & - & - & - & - \\
\hline Height of Skull at Auditory Meatus & 116.0 & 35.6 & 110.0 & 35.0 & - & - & - & - \\
\hline Height of Canines above Alveoli (upper) & 31.4 & 9.6 & 34.0 & 10.8 & - & - & - & - \\
\hline Height of Canines above Alveoli (lower) & 33.0 & 10.1 & 34.0 & 10.8 & - & - & - & - \\
\hline Length of Lower Post-canine series & 81.0 & 24.8 & - & - & - & - & - & - \\
\hline Length of Lower Toothrow & 116.5 & 35.7 & & & - & - & - & - \\
\hline Length of Upper Post-canine series & 81.5 & 25.0 & 85.0 & 27.1 & 104.2 & 26.8 & 92.0 & 27.9 \\
\hline Length of Upper Toothrow & 116.5 & 35.7 & - & - & - & - & - & - \\
\hline Length of Palate & 129.5 & 39.7 & - & - & - & - & 142.0 & 43.0 \\
\hline Foramen Magnum Length & 37.3 & 11.4 & 36.0 & 11.5 & - & - & - & - \\
\hline Foramen Magnum Width & 35.0 & 10.7 & 34.0 & 10.8 & - & - & - & - \\
\hline Mandibular Length & 236.0 & 72.4 & 237.0 & 75.5 & 306.0 & 78.7 & - & - \\
\hline Mandibular Width & 22.2 & 6.8 & 23.0 & 7.3 & - & - & - & - \\
\hline Mandibular Heigth at M1 & 33.0 & 10.1 & - & - & - & - & - & - \\
\hline Upper Dental Formula & $2-1-5$ & & $2-1-5$ & & - & & - & \\
\hline Lower Dental Formula & $2-1-4 / 5$ & & $2-1-5$ & & - & & - & \\
\hline Sutural Age & 11 & & - & & - & & - & \\
\hline
\end{tabular}

Obs.: Measurements are based on Burns and Fay (1970) and expressed in mm; in case of bilateral measurements, only the left one was taken. Sutural age was calculated following Sivertsen (1954).

\section{Acknowledgements}

The present study was financed by grants from Universidad Nacional de Mar del Plata (Projects 15/E005 and 15/E102) and Agencia Nacional de Promoción Científica y Tecnológica (PICT97 07-00000-01651 and PICT99 0107111).
Beach surveys were performed in cooperation with Fundación Mundo Marino (San Clemente del Tuyú, Argentina). Daniel E. Naya (Sección Zoología Vertebrados, Facultad de Ciencias, Universidad de la República, Uruguay) kindly provided unpublished information on leopard seal records in Uruguay. Lic. Hugo Castello and 
Dr. Diego Verzi confirmed us the absence of Hydrurga samples in the marine mammal collections of Museo Argentino de Ciencias Naturales and Museo de La Plata respectively. Nathan McNally provided helpful comments on early drafts of this article.

\section{References}

Bester, M.N. (1981) Fur seals Arctocephalus gazella and leopard seals Hydrurga leptonyx at the Courbet Peninsula, Kerguelen. South African Journal of Antarctic Research 10/11: 35-37.

Bester, M.N. and Roux, J.P. (1986) Summer presence of leopard seals Hydrurga leptonyx at the Courbet Peninsula, Iles Kerguelen. South African Journal of Antarctic Research 16: 29-32.

Borsa, P. (1990) Seasonal occurrence of the leopard seal, Hydrurga leptonyx, in Kerguelen Islands. Canadian Journal of Zoology 68: 405-408.

Brown, K.G. (1957) The leopard seal at Heard Island, 1951-1954. Australian National Antarctic Research Expedition, Interim Reports 16: 1-34.

Burns, J.J. and Fay, F.H. (1970) Comparative morphology of the skull of the ribbon seal, Histriophoca fasciata, with remarks on systematics of Phocidae. Journal of Zoology 161: 363-394.

Castello, H.P. and Rumboll, M. (1978) Extension of range of the leopard seal, Hydrurga leptonyx, for the Argentine coast. Mammalia 42: 135-137.

Crespo, E., Reyes, L., Garcia, N., Koen Alonso, M. and Dans, S. (1992) Revision biogeográfica de los mamíferos marinos presentes en las costas del norte y centro de Patagonia. Page 19 in Resúmenes, Quinta Reunión de Trabajo de Especialistas en Mamíferos Acuáticos de América del Sur, 28 September-2 October, Buenos Aires, Argentina.

De Master, D., Thomas, J., Stone, S. and Adrashek, D. (1979) Biological studies of seals in pack ice habitat. Antarctic Journal 14: 179-180.

Erickson, A.W., Siniff, D.B., Cline, D.R. and Hofman, R.J. (1971) Distributional Ecology of Antarctic seals. Pages 55-76 in Deacon, G. (Ed.) SCAR Symposium on Antarctic Ice and Water Masses, July 19, 1970, Tokyo, Japan.

Ferreira, H.D.O., Zerbini, A.N. and Siciliano, S. (1995) Occurrence of crabeater and leopard seals in Southern Brazil. Page 36 in Abstracts, XI Biennial Conference on the Biology of Marine Mammals, 14-18 December, Galveston, USA.

Goodall, R.N.P. and Schiavini, A.C.M. (1987) Focas antárticas halladas en las costas de Tierra del Fuego. Pages 57-59 in Anais II Reunião de Trabalho de Especialistas em Mamíferos Aquáticos da America do Sul, 4-8 August, Rio de Janeiro, Brazil.

Gwynn, A. M. (1953) The status of leopard seal at Heard Island and Macquarie Island, 1948-50. Australian National Antarctic Research Expedition, Interim Report 3: 1-33.

Hamilton, J.E. (1939) The leopard seal, Hydrurga leptonyx (de Blainville). Discovery Reports 18: 239-264.

Harrison, R.J. (1969) Reproduction and reproductive organs. Pages 253342 in Anderson, H.T. (Ed.) The Biology of Marine Mammals. Academic Press, New York, USA.

Hofman, R., Reichle, R., Siniff, D.B. and Muller-Schwarze, D. (1977) The leopard seal (Hydrurga leptonyx) at Palmer Station. Pages 769-782 in Llano, G. (Ed.) Adaptations within Antarctic Ecosystems. Smithsonian Institution, Washington DC, USA.

King, J.E. (1983) Seals of the World, 2nd ed. British Museum (Natural History) and Oxford University Press, Oxford, UK.

Kooyman, G.L. (1981) The leopard seal (Hydrurga leptonyx Blainville 1820). Pages 261-274 in Ridgway, S.H. and Harrison, R.J. (Eds) Handbook of Marine Mammals, vol.2. Academic Press, London, UK.
Laws, R.M. (1957) On the growth rates of the leopard seal (Hydrurga leptonyx de Blainville). Saugertiekunde Mitt 5: 49-55.

Laws, R.M. (1984) Seals. Pages 612-715 in Laws, R.M. (Ed.) Antarctic Ecology, vol.2. Academic Press, New York, USA.

Naya, D.E. and Achaval, F. (Ms) Nuevos registros de especies poco comunes de Pinnipedia y primer registro de Arctocephalus gazella (Peters, 1875) (Pinnipedia: Otariidae) para el Uruguay. Manuscript in evaluation in Boletín de la Sociedad Zoologica del Uruguay (2da Epoca). 8pp.

Pinedo, M.C. (1990) Ocorrência de pinípedes na costa brasileira. Garcia de Orta (Série Zoologia) 15: 37-48.

Reeves, R.R., Stewart, B.S. and Leatherwood, S. (1992) The Sierra Club Handbook of Seals and Sirenians. The Sierra Club Books, San Francisco, USA.

Rosas, F.C.W., Capistrano, L.C., Di Beneditto, A.P. and Ramos, R. (1992) Hydrurga leptonyx recovered from the stomach of a tiger shark captured off the Rio de Janeiro coast, Brazil. Mammalia 56: $153-155$.

Rounsevell, D. (1988) Periodic irruptions of itinerant leopard seals within the Australasian sector of the Southern Ocean. Papers and Proceedings of the Royal Society of Tasmania 122: 89-92.

Rounsevell, D. and Eberhard, I. (1980) Leopard seals, Hydrurga leptonyx (Pinnipedia), at Macquarie Island from 1949 to 1979. Australian Wildlife Research 7: 403-415.

Sinha, A.A. and Erickson, A.W. (1974) Untraestructure of the placenta of Antarctic seals during the first third of pregnancy. American Journal of Anatomy 14: 263-280.

Siniff, D.B. and Bengston, J.L. (1977) Observations and hypotheses concerning the interactions among crabeater seals, leopard seals, and killer whales. Journal of Mammalogy 58: 414-416.

Siniff, D.B. and Stone, S. (1985) The role of the leopard seal in the trophodynamics of the Antarctic marine ecosystem. Pages 561-565 in Siegfred, W.R., Condy, P.R. and Laws, R.M. (Eds) Antarctic nutrient cycles and food webs. Springer-Verlag, Berlin, Germany.

Siniff, D.B., Stirling, I., Bengston, J.L. and Reichle, R.A. (1979) Social and reproductive behavior of crabeater seals (Lobodon carcinophagus) during the austral summer. Canadian Journal of Zoology 57: 2243-2255.

Sivertsen, E. 1954. A survey of the Eared Seals (Family Otariidae) with remarks on the Antarctic Seals collected by the M/K "Norvegia" in 1928-1929. Scientific Results of the Norwegian Antarctic Expeditions 1927-1928 et subsequents, 36. Det Norske Videnskaps-Akademi i Oslo. 76pp.

Testa, J.W., Oehlert, G., Ainley, D.G., Bengston, J.L., Siniff, D.B., Laws, R.M. and Rounsevell, D. (1991) Temporal variability in Antarctic marine ecosystems: periodic fluctuation in phocid seals. Canadian Journal of Fisheries and Aquatic Sciences 48: 631-639.

Vaz Ferreira, R. (1984) La foca leopardo Hydurga leptonyx (de Blainville, 1820) (Pinnipedia: Phocidae) en el Uruguay. Boletín de la Sociedad Zoologica del Uruguay (2da Epoca) 2: 18-21.

Walker, T.R., Boyd, I.L., McCafferty, D.J., Huin, N., Taylor, R.I. and Reid, K. (1998) Seasonal occurrence and diet of leopard seals (Hydrurga leptonyx) at Bird Island, South Georgia. Antarctic Science 10: 75-81.

Widholzer, F.L. (1982) Registro de uma nova espécie de mamifero para o Brasil, Hydrurga leptonyx (Blainville) (Carnivora Phocidae). Page 263 in Resumos IX Congresso Brasileiro de Zoologia, 7-13 February, Porto Alegre, Brazil.

Ximenez, A., Simões-Lopes, P.C. and Praderi, R. (1987) Notas sobre mamiferos marinos de Santa Catarina e Rio Grande do Sul (Pinnipedia, Cetacea). Pages 100-103 in Anais II Reunião de Trabalho de Especialistas em Mamíferos Aquáticos da América do Sul, 4-8 August, Rio de Janeiro, Brazil. 